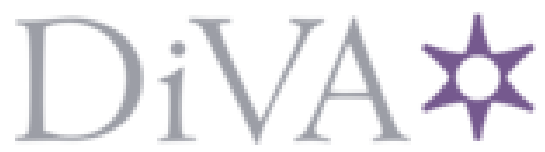

http://www.diva-portal.org

This is the published version of a paper published in The Lichenologist.

Citation for the original published paper (version of record):

Otálora, M A., Wedin, M. (2013)

Collema fasciculare belongs in Arctomiaceae.

The Lichenologist, 45(3): 295-304

http://dx.doi.org/10.1017/S0024282912000849

Access to the published version may require subscription.

N.B. When citing this work, cite the original published paper.

Permanent link to this version:

http://urn.kb.se/resolve?urn=urn:nbn:se:nrm:diva-65 


\title{
Collema fasciculare belongs in Arctomiaceae
}

\author{
Mónica A. G. OTÁLORA and Mats WEDIN
}

\begin{abstract}
The phylogenetic placement of Collema fasciculare (L.) F. H. Wigg, the most deviating species within Collema (Collemataceae, Lecanoromycetidae), was studied using maximum likelihood and Bayesian analysis of three molecular loci (mitochondrial SSU rDNA, and the protein-coding, nuclear RPB1 and MCM7 genes). Collema fasciculare belongs to Arctomiaceae (Ostropomycetidae) forming a strongly supported monophyletic group with members of Arctomia. The spores, paraphyses, asci and hymenial reactions in Collema fasciculare are similar to other Arctomia, but the ascoma ontogeny is somewhat different. Also C. leptosporum Malme, another species in the Fasciculare group, shows similarities with Arctomia regarding spores and asci. Arctomia is morphologically heterogeneous and the genus is in need of revision. Until then, the species of the Fasciculare group fit best in Arctomia s. lat. and the combinations Arctomia fascicularis (L.) Otálora \& Wedin, Arctomia leptospora (Malme) Otálora \& Wedin, Arctomia papuanarum (Degel.) Otálora \& Wedin and Arctomia uviformis (Hue) Otálora \& Wedin are proposed.
\end{abstract}

Key words: Arctomia, ascoma ontogeny, Collemataceae, cyanolichens, lichens, taxonomy

\section{Introduction}

During recent decades, tremendous progress has been made in understanding relationships among Ascomycota by using DNA sequence data (Lutzoni et al. 2004; Miadlikowska et al. 2006; Hibbett et al. 2007; Ekman et al. 2008). As a consequence, the classification of Ascomycetes has undergone substantial changes (Hibbett et al. 2007; Kirk et al. 2008; Lumbsch \& Huhndorf 2009). In addition, the constant increase in the number of taxa in phylogenetic studies has also revealed the phylogenetic placement of sterile or enigmatic taxa. In the lichenforming Ascomycetes associating with cyanobacteria (cyanolichens), several recent major taxonomic changes have been proposed (Lumbsch et al. 2005; Wedin et al. 2009; Otálora et al. 2010; Muggia et al. 2011; Spribille \& Muggia 2012). Molecular phylogenies suggest that cyanolichens form three

M. A. G. Otálora and M. Wedin: Cryptogamic Botany, Swedish Museum of Natural History, P.O. Box 50007, SE-104 05 Stockholm, Sweden.

Email: monica.garcia.otalora@gmail.com distinct and distantly related lineages: Arctomiaceae (Lumbsch et al. 2005; Wedin et al. 2005) and the Peltigerales (Wedin et al. 2005; Miadlikowska et al. 2006) in the Lecanoromycetes, and Lichinales in the Lichinomycetes (Reeb et al. 2004).

Although the Peltigerales is by far the most species-rich cyanolichen group, it contains lineages that have not yet been well studied. One of these is the Collemataceae s. str., a group of distinctly gelatinous cyanolichens which comprises two large genera; Collema F. H. Wigg. with $c .80$ currently accepted species, and Leptogium (Ach.) Gray with c. 180 species (Kirk et al. 2008). The detailed phylogenetic relationships within the Collemataceae are still unclear, despite some recent studies (Otálora et al. 2008, 2010; Wedin et al. 2009). Although these studies have confirmed that Collema and Leptogium are non-monophyletic, they have also shown that the traditional family delimitation (Henssen 1965; Henssen \& Jahns 1974; Henssen et al. 1981) did not reflect the phylogenetic relationships. Most genera previously classified in Collemataceae were shown to belong to 
Pannariaceae (Wedin et al. 2009; Otálora et al. 2010), and currently only Collema and Leptogium constitute the Collemataceae.

Another group of cyanolichens that was earlier considered to belong to Peltigerales is Arctomiaceae. Arctomiaceae was originally proposed by Fries (1860), but never gained wide acceptance, and Arctomia Th. Fr. was included in Collemataceae by Zahlbruckner (1925). Henssen (1969), however, resurrected Arctomiaceae, based on differences in the ascoma development between Arctomia and Collemataceae. Molecular sequence data confirmed that Arctomiaceae is distantly related to Collemataceae and suggested that it belongs to Ostropomycetidae (Lumbsch et al. 2005; Wedin et al. 2005).

When studying the phylogenetic relationships within Collemataceae s. str., we soon found that the most deviating species regarding spore and apothecial characteristics within Collema [C. fasciculare (L.) F. H. Wigg.] not only grouped outside Collemataceae, but also outside the Peltigerales. Preliminary BLAST searches suggested similarities to Arctomiaceae. Collema fasciculare is a widely distributed, epiphytic species, forming rounded cushions usually up to $c .2 \mathrm{~cm}$ diam. (rarely up to $7 \mathrm{~cm}$ ) with a crustose to subfoliose, indistinctly lobed thallus, which becomes swollen and gelatinous when wet. Similar to Collema, it associates with Nostoc, has a homoiomerous thallus organization without a true cortex, lecanorine apothecia with a persistent thalline exciple, and lacks secondary metabolites. However, it differs from other Collema species in some distinct ascomatal traits. The paraphyses and ascospores of $C$. fasciculare are comparatively more flexuous and thinner than in other Collema species (Degelius 1954, 1974), and the proper exciple is poorly developed or sometimes absent. Based on these differences, Degelius proposed the informal subgeneric Fasciculare group in which he included the widely distributed species $C$. fasciculare (Degelius 1954) and the three rare or poorly collected tropical species $C$. uviforme Hue, C. papuanorum Degel., and C. leptosporum Malme (Degelius 1974). Although the morphological differences between the members of the Fasciculare-group and other Collema species have largely been recognized and accepted by other lichenologists (Filson 1992; Jørgensen 2007), no molecular studies have investigated the phylogenetic position of any member of this group.

The aim of this study is to investigate the phylogenetic placement of $C$. fasciculare. To achieve this we performed phylogenetic analyses, including representatives from the two lineages of Lecanoromycetes where cyanolichens are classified (Peltigerales and Arctomiaceae), based on sequences of the mitochondrial SSU rDNA and the protein coding genes RPB1 (RNA polymerase II subunit 1) and MCM7. In order to identify morphological characters that explain the phylogenetic placement of $C$. fasciculare, we also studied the ascus structure and the ascoma ontogeny. In addition, we studied material of one other species of the Fasciculare group, C. leptosporum, and of Arctomia s. str., for comparison.

\section{Materials and Methods}

\section{Specimens and markers}

We used the mtSSU rDNA, RPB1 and MCM7 loci from a total of 35 species of Lecanoromycetes. Collema fasciculare was represented by four specimens originating from different parts of the world (New Zealand, Spain and Sweden). The other species of the Fascicularegroup were not represented in the sampling due to the lack of recent material. Only the sequences of $C$. fasciculare were generated for this study, the rest were obtained from GenBank (Table 1). A total of $39 \mathrm{mtSSU}$ rDNA, $37 \mathrm{RPB} 1$ and $23 \mathrm{MCM} 7$ sequences were included in this study.

Additional material examined. Arctomia delicatula $\mathrm{Th}$. Fr.-Sweden: Torne Lappmark: Karesuando par., Pältsan (Bealccan). alt. $1110 \mathrm{~m}, 2011$, M. Westberg P108 (S).

Collema leptosporum Malme.-Brazil: Mato Grosso: Corumbá, in silva clararegionis calcariae, 14 viii 1894 , Malme [Malme Lich. austr. amer. Exs. No 70] (S).

\section{DNA sequencing}

Total genomic DNA was extracted using DNeasy (Qiagen) according to the manufacturer's instructions. The mtSSU rDNA was amplified using the primers mtSSU1 and mtSSU3R (Zoller et al. 1999); the protein coding gene RPB1 using primers RPB1-Af (Stiller \& Hall 1997) and RPB1-6R1asc (Hofstetter et al. 2007); 
TABLE 1. List of taxa included in this study and GenBank accession numbers. Nerw sequences are indicated in bold

\begin{tabular}{|c|c|c|c|c|}
\hline \multirow[b]{2}{*}{ Species } & & \multicolumn{3}{|c|}{ GenBank accession number } \\
\hline & & $\mathrm{mtSSU}$ & RPB1 & MCM7 \\
\hline Arctomia borbonica 1 & & JX030032 & JX030034 & - \\
\hline A. borbonica 2 & & JX030033 & JX030035 & - \\
\hline A. delicatula & & AY853307 & DQ870929 & GQ272388 \\
\hline A. interfixa & & DQ007348 & - & - \\
\hline A. teretiuscula & & DQ007349 & DQ870930 & GQ272389 \\
\hline Aspicilia caesiocinerea & & DQ780271 & DQ870931 & GQ272390 \\
\hline A. cinerea & & DQ780272 & DQ870932 & GQ272391 \\
\hline Coccotrema cucurbitula & & AF329161 & DQ870939 & GU980990 \\
\hline C. pocillarium & & AF329166 & DQ870940 & GU980992 \\
\hline Collema fasciculare 1 & Spain, Aragón E Marti. 3417 (MA) & KC118988 & KC118991 & KC118995 \\
\hline C. fasciculare 2 & Sweden, Karström 562 (UPS) & KC118987 & KC118993 & KC118997 \\
\hline C. fasciculare 3 & Spain, Aragón 1041/95 (MA) & KC118989 & KC118992 & KC118996 \\
\hline C. fasciculare 4 & New Zealand, Wedin 8753 (S) & KC118990 & KC118994 & KC118998 \\
\hline C. furfuraceum & & EU982567 & GQ259048 & JX992982 \\
\hline C. nigrescens & & EU982563 & GQ259049 & JX992989 \\
\hline Diploschistes scruposus & & AY584692 & DQ870943 & JX000163 \\
\hline Graphis scripta & & AY853322 & DQ870947 & JX000164 \\
\hline Gregorella humida & & AY853329 & DQ870946 & - \\
\hline Lecanora paramerae & & EF105418 & DQ870950 & - \\
\hline Lepraria lobificans & & DQ986887 & DQ986837 & - \\
\hline Leptogium lichenoides & & DQ923120 & DQ917414 & JX993021 \\
\hline L. saturninum & & EU982569 & GQ259064 & JX992985 \\
\hline Lobaria pulmonaria & & AY340504 & DQ915591 & JX000169 \\
\hline Ochrolechia parella & & GU980977 & DQ870959 & GQ272421 \\
\hline Pannaria rubiginosa & & AY340513 & GQ259074 & JX993042 \\
\hline Peltigera aphthosa & & AY340515 & DQ915598 & JX000176 \\
\hline Pertusaria amara & & AY300900 & DQ870965 & GQ272423 \\
\hline P. corallina & & AY300901 & DQ870967 & GU980997 \\
\hline Placynthium nigrum & & EU982566 & GQ259079 & - \\
\hline Protopannaria pezizoides & & AY340519 & GQ259081 & - \\
\hline Protothelenella corrosa & & AY607746 & DQ870988 & - \\
\hline P. sphinctrinoidella & & AY607747 & DQ870989 & - \\
\hline Ramalina complanata & & DQ972986 & DQ973059 & - \\
\hline Rhizocarpon sphaerosporum & & AY853340 & DQ870991 & - \\
\hline Schaereria corticola & & AY300909 & DQ870993 & - \\
\hline Sphaerophorus globosus & & DQ986866 & DQ986836 & JX000185 \\
\hline Thelenella antarctica & & AY607749 & - & - \\
\hline T. muscorum & & AY607743 & FJ941910 & \\
\hline Wawea fruticulosa & & DQ871023 & DQ871005 & - \\
\hline
\end{tabular}

and MCM7 using the primers MCM7-709 and MCM7 1348 (Schmitt et al. 2009). PCR amplifications were performed using IllustraTM Hot Start PCR beads, according to the manufacturer's instructions. PCRreactions were performed using the following cycling parameters: initial denaturation $95^{\circ} \mathrm{C}$ for $5 \mathrm{~min}$, and 35 (mtSSU rDNA) or 40 (MCM7 and RPB1) cycles at $95^{\circ} \mathrm{C}$ for $1 \mathrm{~min}, 56^{\circ} \mathrm{C}$ for $50 \mathrm{~s}(\mathrm{mtSSU} \mathrm{rDNA}$ and $\mathrm{RPB} 1$ ) or $54^{\circ} \mathrm{C}$ for $1 \mathrm{~min}$ (MCM7), and $72^{\circ} \mathrm{C}$ for 1 min; this was followed by a final extension at $72^{\circ} \mathrm{C}$ for $8 \mathrm{~min}$. PCR products were subsequently purified using the enzymatic method Exo-sap-IT provided by USB Corporation. Unidirectional dye-terminated sequencing for the forward and reverse reactions using the same 
PCR primers were performed on an ABI 377 automated sequencer using Big Dye Terminator technology (Applied Biosystems, Warrington).

\section{Phylogenetic methods}

Alignments were constructed separately for each locus with the online version of MAFFT 6 using the auto option (Katoh \& Toh 2008). In the case of mtSSU rDNA, ambiguous regions were delimited using GUIDANCE web service with the default cut-off of 0.95 (Penn et al. 2010). The alignments for the protein coding genes were adjusted in MacClade 4.01 (Maddison \& Maddison 2001), utilizing the amino acid translations. Delimited ambiguous regions and introns were excluded from the phylogenetic analyses.

Phylogenetic relationships and confidence were inferred with a maximum likelihood (ML) and Bayesian approach (MB). The combinability of the single locus data sets was assessed by visual inspection of the individual bootstrap values (Mason-Gamer \& Kellogg 1996; Wiens 1998). A conflict was considered significant when two data partitions supported conflicting monophyletic groups with $\mathrm{ML}$ bootstrap values $\geq 70 \%$ in both trees. Because no significant conflicts were detected, it was assumed that the two data sets were congruent and could be combined. We constructed two different combined data sets, first a two-locus data set (mtSSU rDNA+RPB1) with two taxa having missing data for RPB1, and second a three-locus (mtSSU rDNA+RPB1+MCM7) dataset with 16 taxa having missing data for MCM7. Maximum likelihood analyses were performed on the two combined data sets using RAxML-HPC2 (Stamatakis 2006; Stamatakis et al. 2008) and implementing a GTRCAT model for the bootstrapping phase, and GTRGAMMA for the final tree inference using 4 and 7 partitions for the 2-locus data set and the 3-locus data set, respectively (three codon positions for each RPB1 and MCM7). In addition, a bootstrap analysis of 1000 pseudoreplicates was performed for each data set. The analyses were performed on the Cipres Web Portal (Miller et al. 2010).

The evolutionary models for Bayesian analyses were selected using the Bayesian Information Criteria (BIC), as implemented in JModeltest 3.06 (Posada 2008). The GTR+G model was used for mtSSU and RPB1 first position; SYM+G for RPB1 second position and MCM7 first and second position; and $\mathrm{HKY}+\mathrm{I}+\mathrm{G}$ for $\mathrm{RPB} 1$ third position and MCM7 third position. The Bayesian analyses were performed using MrBayes 3.2.0 (Ronquist et al. 2011). Two runs of 4 million generations, starting from an initial random tree and employing four simultaneous chains, were executed. A tree was saved every 100 th generation. To ensure that stationarity was reached and the runs converged at the same log-likelihood levels, we plotted the log-likelihood scores of sample points against generation time using Tracer 1.5 (Rambaut \& Drummond 2007). The first 10000 trees from each run were discarded as 'burn-in'. For the remaining trees in each analysis, a majority-rule consensus tree was assembled using the sumt option of MrBayes. The .con file created by MrBayes was visualized in FigTree V.1.3.1 (Rambaut 2009).

\section{Morphological study}

For the ontogenetic study, serial sections through thallus parts with different apothecial stages were prepared using a freezing microtome. The sections were mounted in lactophenol cotton blue and studied by light microscopy. Asci were studied on material mounted in water using hand-cut sections, before and after staining with Lugol's iodine solution, with and without pretreatment with $10 \% \mathrm{KOH}$.

\section{Results}

Twelve new sequences were generated in this study, four for each of the genes. These new sequences were aligned with 83 sequences obtained from GenBank (Table 1). After excluding 514 ambiguously aligned sites, the 3-locus data set contained 1807 sites, of which 984 were variable. Of the variable sites, 338 belonged to the $\mathrm{mtSSU}$ partition, 367 to RPB1 and 279 to the MCM7. In the 2-locus data set, the entire MCM7 partition was excluded. Maximum likelihood analyses resulted in a single most likely tree with ln-likelihood of $-15922 \cdot 3654$ for the 2-locus and $-21191 \cdot 7847$ for the 3locus data sets. The majority rule consensus trees from the Bayesian analyses were based on 60000 credible trees from two runs for each one of the data sets. The harmonic mean $\ln$-likelihood was -15985.49 for the 2 locus data set and $-21228 \cdot 13$ for the 3-locus data set. The tree topologies obtained from the 2-locus and 3-locus data sets did not show any significant conflict in either of the two methods of analysis, but the 3-locus data set resulted in lower branch support. Only the best tree from the maximum likelihood analysis of the 2-locus analysis is thus presented here, with both bootstrap support and posterior probabilities from both data sets (Fig. 1).

\section{Morphological study}

The earliest stages in the ascomatal development that we found were young primordia situated under the thallus surface in shallow thallus outgrowths (Fig. 2A). We did not see any stage corresponding to the outgrowth of generative tissue typical for the Arctomiaceae (Henssen 1969; Henssen \& Kantvilas 1985; 


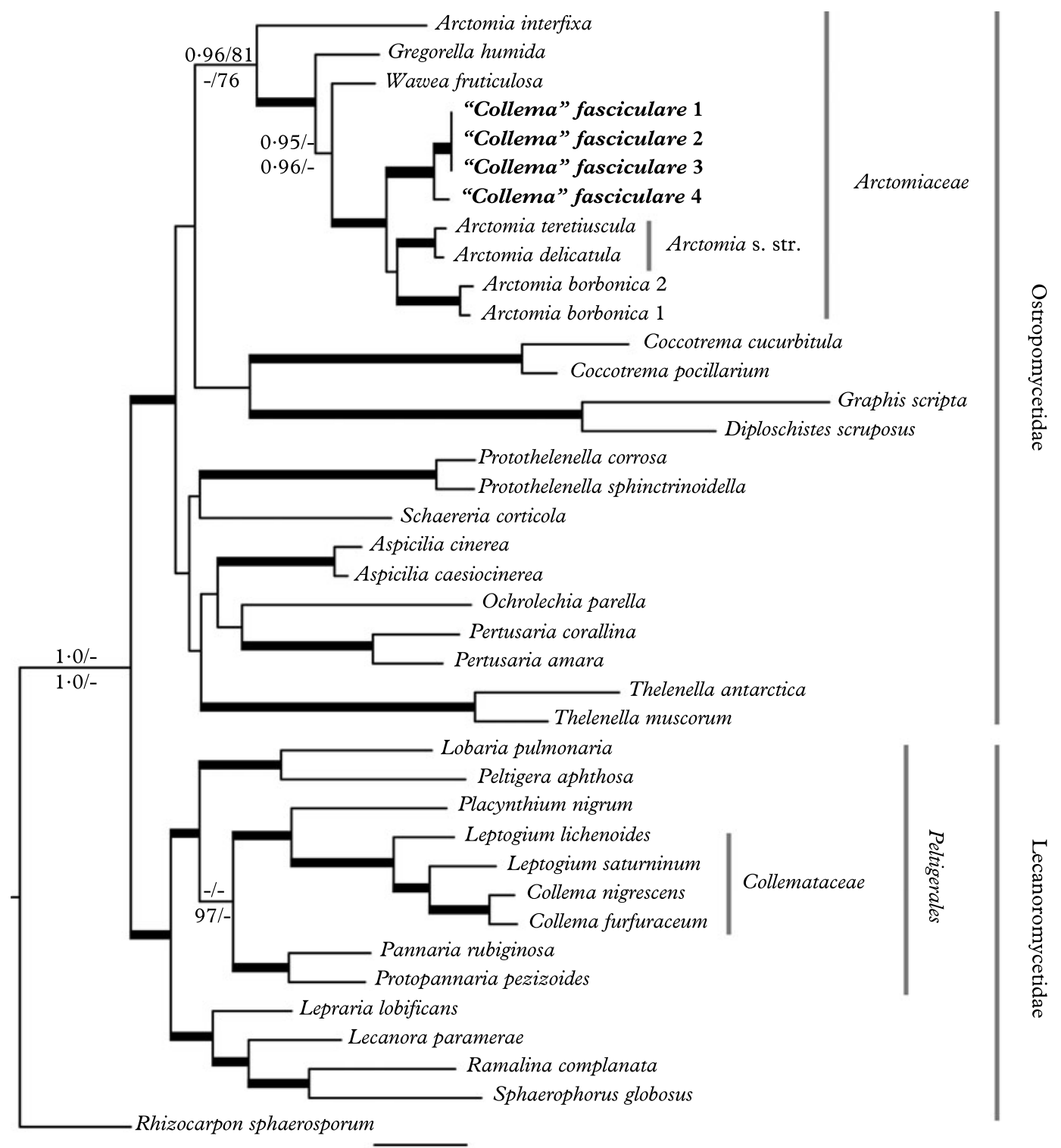

$0 \cdot 09$

FIG. 1. Phylogenetic relationships of cyanobacterial lichens within the Lecanoromycetes. Support values above branches correspond to the values obtained from the 2-locus data set, and support values below branches correspond to the ones obtained from the 3-locus data set (mtSSU rDNA+RPB1+MCM7). Thicker internodes indicate significant support in the two data sets for the two phylogenetic methods (PP >0.95, ML BS > 70). Collema fasciculare constitutes a monophyletic group sister to the rest of Arctomia s. str., within a monophyletic Arctomiaceae in the Ostropomycetideae.

Lumbsch et al. 2005), despite several attempts, although we cannot rule out that such a stage occurred but quickly became overgrown by thallus tissue. When the pri- mordium grows and reaches the thallus surface (Fig. 2B \& C), the upper surface disintegrates and a simple, very thin primordium wall is differentiated (Fig. 2C \& D). This 

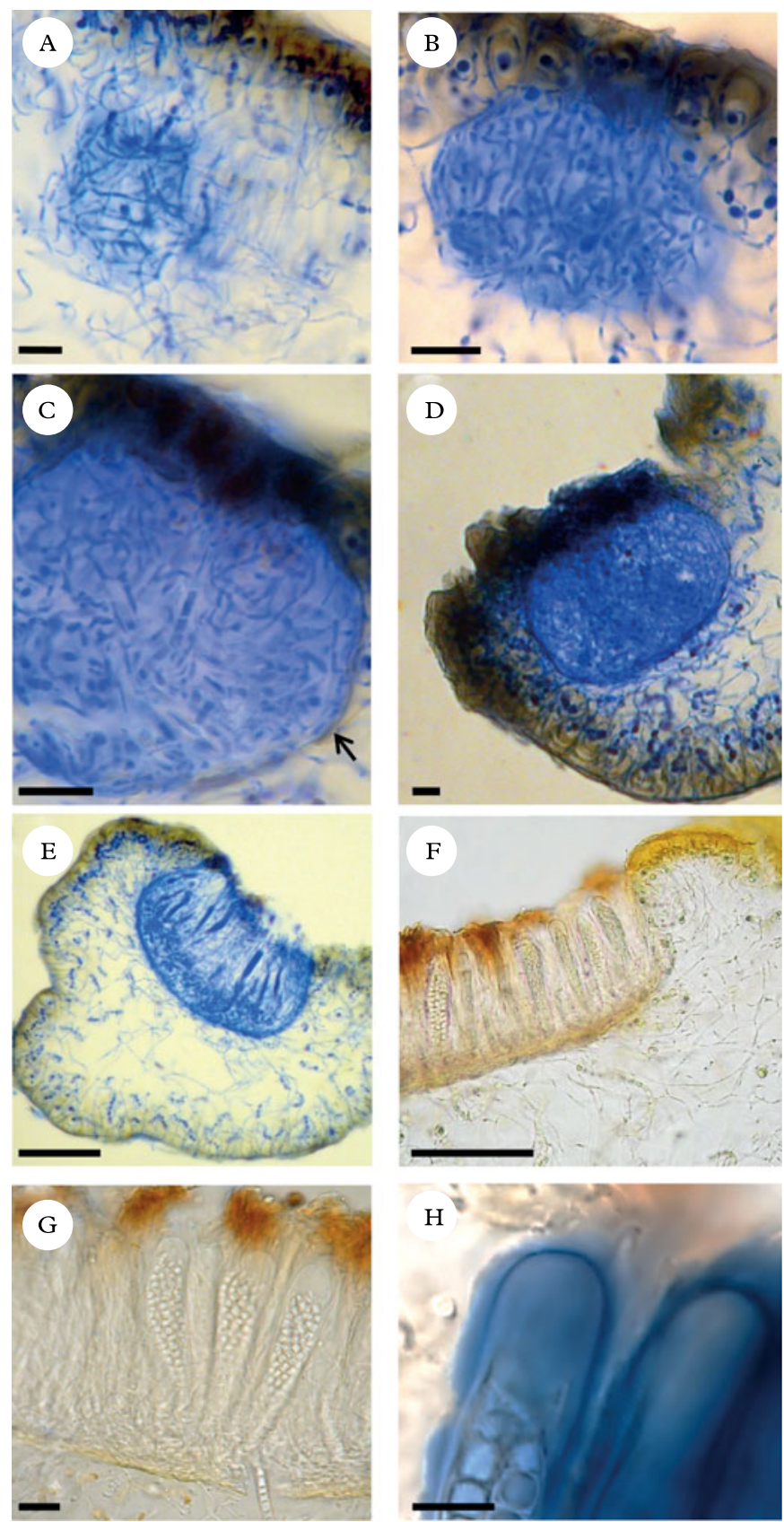

FIG. 2. Ascoma development in Collema fasciculare [Karström 562 (UPS)]. A, young primordium situated under the thallus surface; $\mathrm{B}$, somewhat older primordium reaching the thallus surface; C, older primordium where a thin, slightly pigmented wall is differentiated (arrow); $\mathrm{D}$, older primordium where the upper surface is disintegrating during the development; E, older stage showing young asci and young paraphyses; F, marginal part of mature apothecium with pigmented epihymenium and thalline exciple visible; G, detail showing the proper exciple, asci and ascospores; $\mathrm{H}$, detail of asci in Lugol's iodine solution after pre-treatment with $\mathrm{KOH}$. Scales: A-D, G \& $\mathrm{H}=10 \mu \mathrm{m} ; \mathrm{E} \& \mathrm{~F}=100 \mu \mathrm{m}$. 
wall is composed of thin-walled, slightly pigmented hyphae (Fig. 2C), which in the mature stage form the thin proper exciple (Fig. 2E-G). When the developing hymenium is exposed, asci and paraphyses are visible (Fig. 2E), and at the mature stage (Fig. 2F), an indistinct, thin thalline exciple is present. The paraphyses are thin $(1.0-1.5 \mu \mathrm{m})$ and lax, branched, and distinctly brown-pigmented at the apices (Fig. 2G) which are slightly swollen. The ascus wall is I+ reddish to blue, $\mathrm{KOH} / \mathrm{I}+$ blue, and the tholus contains no amyloid structures (Fig. 2H). It contains eight long (c. $65-170 \mu \mathrm{m})$ and thin $(c .4 \cdot 5-5 \cdot 0 \mu \mathrm{m})$ spores formed by $10-17$ cells (Fig. $2 \mathrm{G} \& \mathrm{H}$ ).

We also studied sections of $C$. leptosporum, for comparison. In C. leptosporum, the proper exciple is distinct, euparaplectenchymatous and thick $(70-105 \mu \mathrm{m})$; the paraphyses are 1.5-2.0 $\mu \mathrm{m}$ thick, simple and slightly swollen at the apices. Collema leptosporum has ascus characteristics similar to $C$. fasciculare, and the spores are also long $(115-160 \mu \mathrm{m})$ and thin $(2-4 \mu \mathrm{m})$, formed by $6-8$ cells.

\section{Discussion}

The two cyanolichen lineages within Lecanoromycetes are both recovered here as monophyletic. Arctomiaceae formed a weaklysupported clade within Ostropomycetidae, and Peltigerales formed a well-supported clade within Lecanoromycetidae (Fig.1). These results agree with previous Lecanoromycete studies (Lumbsch et al. 2005, 2007; Wedin et al. 2005). The monophyly of Arctomiaceae is well supported in the 2-locus analysis, but lacks Bayesian support in the 3locus analysis. This is probably due to the large amount of missing data in the MCM7 data set. The backbone of the topology within Ostropomycetidae lacks support, which makes the detailed relationships of Arctomiaceae within this group uncertain. All analyses supported the monophyly of the four specimens of $C$. fasciculare with high confidence (1.0 PP, $100 \mathrm{ML})$ as a member of the monophyletic Arctomiaceae. Arctomia delicatula, $A$. borbonica Magain \& Sérus., $A$. teretiuscula
P. M. Jørg. and C. fasciculare form a wellsupported monophyletic group. Collema fasciculare is thus suggested here to belong to Arctomia. Arctomia was previously considered monophyletic (Lumbsch et al. 2005) but in our investigation it is paraphyletic, with $A$. interfixa (Nyl.) Vain. as sister to the rest of Arctomiaceae, including Gregorella Lumbsch and Wawea Henssen \& Kantvilas. This is similar to the result of Magain \& Sérusiaux (2012), who considered $A$. interfixa to be of uncertain position within Arctomiaceae, and who interpreted the paraphyly of Arctomia as the result of an incomplete data set. It should be noted that we too have no data of MCM7 and RPB1 for $A$. interfixa, and therefore this relationship is also uncertain in our investigation. The phylogenetic relationship between Gregorella humida and Wawea fruticulosa is also uncertain. Lumbsch et al. (2005) and Magain \& Sérusiaux (2012) found them to form a well-supported monophyletic group, but neither our study nor Lumbsch et al. (2007) supported that relationship. The fact that Arctomiaceae is monophyletic including Collema fasciculare is, however, beyond doubt.

Degelius previously (1954: 103) suggested that, in view of the different type of ascospores and paraphyses, C. fasciculare should better be recognized as a separate genus. This recognition was never done, probably because of the many characteristics that this species shares with various species of $\mathrm{Col}$ lema. For instance, C. fasciculare is similar to $C$. leptaleum Tuck. regarding habit. The anatomical characteristics of the thallus are similar to C. multipartitum Sm. and C. multipunctatum Degel., and the apothecial habit is similar to several other Collema species (Degelius 1954, 1974; Jørgensen 2007).

The ascoma ontogeny was the criterion used by Henssen (1969) to delimit the Arctomiaceae. The ontogeny had not been studied earlier in $C$. fasciculare, but our study suggested that there actually are distinct differences compared with other Arctomiaceae. Henssen (1969) excluded Arctomia from Collemataceae because of the distinct external outgrowth of generative tissue in which ascogonia develop, in Arctomia, and because the 
whole ontogeny thus took place above the surface of the thallus proper. In Collemataceae s. str., the development of the ascoma commences within the thallus (beneath the upper surface). Studies after Henssen (1969) have likewise found that the ontogeny in other Arctomiaceae starts with an outgrowth of generative tissue (Henssen \& Kantvilas 1985; Lumbsch et al. 2005). We have no indications that such an outgrowth is produced in $C$. fasciculare, and as far as we have been able to find, the whole ontogeny in $C$. fasciculare takes place within the thallus beneath the upper surface (Fig. 2A), and the resulting apothecia have a distinct thalline excipulum (Fig. 2F).

Even if the ascoma ontogeny deviates somewhat from the typical Arctomiaceae, there are other important similarities. Collema fasciculare is similar to other Arctomia in the spores and paraphyses, the ascus structure, and in the hymenium type. The hymenial gel in C. fasciculare is hemi-amyloid, as in Arctomia. Collema fasciculare possesses asci with a non-amyloid tholus, similar to the Trapelia-type present in some Arctomiaceae (Fig. $2 \mathrm{H}$ ). This ascus type lacks the typical internal amyloid tube structure present in Collema. The ascospores of $C$. fasciculare are further similar to the fusiform, multiseptate ascospores in $A$. delicatula and $A$. teretiuscula. Finally, the paraphyses in $C$. fasciculare are also similar to those in Arctomia.

Arctomia as circumscribed by Henssen (1969) and Jørgensen (2003), includes crustose-squamulose, semi-gelatinous cyanolichens with a single-layered cortex, biatorine apothecia and fusiform, multiseptate ascospores. It could be argued that the putative differences in ascoma ontogeny, and the fact that $C$. fasciculare is sister to Arctomia s. str., would be a reason to accept it as a distinct genus. Several rather deviating new species have been accepted in Arctomia lately, however, and the genus clearly needs a full revision, something that is beyond the scope of this study. Øvstedal \& Gremmen (2001, 2006) described two Arctomia species which have relatively small, ellipsoid ascospores, with 3 transverse septa, which are different to the ones in Arctomia s. str. and $C$. fasciculare. In fact, the authors claimed that these two species do not belong in Arctomia s. str., and that they should be studied further. Recently, Magain \& Sérusiaux (2012) included the new species $A$. borbonica, which also deviates from the typical Arctomia species by producing goniocysts at the lobe margins and by having a thallus that, in general, is similar to the thallus in Leptogium. No apothecia are hitherto known from $A$. borbonica.

Even if including $C$. fasciculare in Arctomia results in a yet more morphologically heterogeneous genus, we believe that this is currently a better option than describing a new genus, as the family now is in desperate need of a thorough revision of the generic delimitations. Collema leptosporum also has asci and ascospores similar to Arctomia and to $C$. fasciculare. This suggests that $C$. leptosporum does not belong to Collema and it could be related to Arctomiaceae, although the proper exciple and paraphyses differ considerably from other Arctomia and from $C$. fasciculare. We feel, however, that C. leptosporum fits considerably better in Arctomia than in Collema. Finally, we suggest that the remaining two species of the Fasciculare-group (which we have not studied material of) should also be better placed in Arctomia, as it is clear from the literature (Degelius 1974) that they share important characteristics with $C$. fasciculare and $C$. leptosporum, particularly the Arctomia-type spores.

\section{Nomenclature}

\section{Arctomia fascicularis (L.) Otálora \& Wedin comb. nov.}

\section{MycoBank No.: MB802158 \\ Basionym: Lichen fascicularis L., Mantissa Pl. 1: 133 (1767). \\ Arctomia leptospora (Malme) Otálora \& Wedin comb. nov.}

MycoBank No.: MB802161

Basionym: Collema leptosporum Malme, Ark. f. Bot. 19 (8): 6 (1924). 


\section{Arctomia papuanarum (Degel.) Otálora \& Wedin comb. nov.}

\section{MycoBank No.: MB802165}

Basionym: Collema papuanorum Degel., Symb. Bot. Upsal. 20 (2): 196 (1974).

\section{Arctomia uviformis (Hue) Otálora \& Wedin comb. nov.}

\section{MycoBank No.: MB802168}

Basionym: Collema uviforme Hue, Bull. Soc. Bot. France 63 (28): 5 (1916).

We thank the curators of the herbaria of MA and UPS, and Gregorio Aragon for the loan of specimens. We also thank the staff at the Molecular Systematics Laboratory at the Swedish Museum of Natural History, who assisted with laboratory work and A. Herrero for advice on nomenclature. This study was supported by the Swedish Research Council (VR 621-2009-537). The first author gratefully acknowledges support from a postdoctoral grant from the Spanish Ministry of Education and Science (EDU3495/2010).

\section{REFERENCES}

Degelius, G. (1954) The lichen genus Collema in Europe: morphology, taxonomy, ecology. Symbolae Botanicae Upsalienses 13: 1-499.

Degelius, G. (1974) The lichen genus Collema with special reference to the extra-European species. Symbolae Botanicae Upsalienses 20: 1-215.

Ekman, S., Andersen, H. L. \& Wedin, M. (2008) The limitations of ancestral state reconstruction and the evolution of the ascus in the Lecanorales (lichenized Ascomycota). Systematic Biology 57: 141-156.

Filson, R. B. (1992) Collema. Flora of Australia 54: 161173.

Fries, T. M. (1860) Lichenes Arctoi Europae Groenlandiaeque Hactenus Cogniti. Uppsala: Leffler.

Henssen, A. (1965) A review of the genera of the Collemataceae with simple spores (excluding Physma). Lichenologist 3: 29-41.

Henssen, A. (1969) Eine Studie uber die Gattung Arctomia. Svensk Botanisk Tidskrift 63: 126-138.

Henssen, A. \& Jahns, H. M. (1973) ('1974') Lichenes. Eine Einführung in die Flechtenkunde. Stuttgart: Georg Thieme Verlag.

Henssen, A. \& Kantvilas, G. (1985) Wawea fruticulosa, a new genus and species from the Southern Hemisphere. Lichenologist 17: 85-97.

Henssen, A., Keuck, G., Renner, B. \& Vobis, G. (1981) The lecanoralean centrum. In Ascomycete Systematics. The Luttrellian Concept. (D. R. Reynolds, ed): 138234. New York, Heidelberg, Berlin: Springer-Verlag.

Hibbett, D. S., Binder, M., Bischoff, J. F., Blackwell, M., Cannon, P. F., Eriksson, O. E., Huhndorf, S., James, T., Kirk, P. M., Lücking, R., et al. (2007) A higher level phylogenetic classification of the Fungi. Mycological Research 111: 509-547.
Hofstetter, V., Miądlikowska, J., Kauff, F. \& Lutzoni, F. (2007) Phylogenetic comparison of protein-coding versus ribosomal RNA-coding sequence data: a case study of the Lecanoromycetes (Ascomycota). Molecular Phylogenetics and Evolution 44: 412-426.

Jørgensen, P. M. (2003) A new species of Arctomia from Sichuan Province, China. Lichenologist 35: 287-289.

Jørgensen, P. M. (2007) Collemataceae. Nordic Lichen Flora 3: 14-42.

Katoh, K. \& Toh, H. (2008) Improved accuracy of multiple ncRNA alignment by incorporating structural information into a MAFFT-based framework. BMC Bioinformatics 9: 212.

Kirk, P., Cannon, P. F., Minter, D. W. \& Stalpers, J. A. (2008) Ainsworth E Bisby's Dictionary of the Fungi. 10th edn. Wallingford: CAB International.

Lumbsch, H. T. \& Huhndorf, S. H. (2009) Myconet Volume 14. Fieldiana, Life and Earth Sciences 1: 164.

Lumbsch, H. T., Prado, R. \& Kantvilas, G. (2005) Gregorella, a new genus to accommodate Moelleropsis humida and a molecular phylogeny of Arctomiaceae. Lichenologist 37: 291-302.

Lumbsch, H. T., Schmitt, I., Mangold, A. \& Wedin, W. (2007) Ascus types are phylogenetically misleading in Trapeliaceae and Agyriaceae (Ostropomycetidae, Ascomycota). Mycological Research 111: 1133-1141.

Lutzoni, F., Kauff, F., Cox, J. C., McLaughlin, D., Celio, G., Dentinger, B., Padamsee, M., Hibbett, D., James, T. Y., Baloch, E., et al. (2004) Assembling the fungal tree of life: progress, classification, and evolution of subcellular traits. American fournal of Botany 91: 1446-1480.

Maddison, W. \& Maddison, D. (2001) MacClade: Analysis of Phylogeny and Character Evolution, Version 4.01. Sunderland, Massachusetts: Sinauer Associates.

Magain, N. \& Sérusiaux, E. (2012) A further new species in the lichen genus Arctomia: A. borbonica from Reunion (Mascarene archipelago). MycoKeys 4: 921.

Mason-Gamer, R. J. \& Kellogg, E. A. (1996) Testing for phylogenetic conflict among molecular data sets in the tribe Triticeae (Gramineae). Systematic Biology 45: $524-545$.

Miądlikowska, J., Kauff, F., Hofstetter, V., Fraker, E., Grube, M., Hafellner, J., Reeb, V., Hodkinson, B. P., Kukwa, M., Lücking, R., et al. (2006) New insights into classification and evolution of the Lecanoromycetes (Pezizomycotina, Ascomycota) from phylogenetic analyses of three ribosomal RNA and two protein-coding genes. Mycologia 98: 10891102.

Miller, M. A., Pfeiffer, W. \& Schwartz, T. (2010) Creating the CIPRES Science Gateway for inference of large phylogenetic trees. In Proceedings of the Gateway Computing Environments Workshop (GCE), 14 November, 2010, New Orleans, p. 1-8.

Muggia, L., Nelson, P., Wheeler, T., Yakovchenko, L. S., Tønsberg, T. \& Spribille, T. (2011) Convergent evolution of a symbiotic duet: the case of the lichen genus Polychidium (Peltigerales, Ascomycota). American fournal of Botany 98: 1647-1656. 
Otálora, M. A. G., Martínez, I., Molina, M. C., Aragón, G. \& Lutzoni, F. (2008) Phylogenetic relationships and taxonomy of the Leptogium lichenoides group (Collemataceae) in Europe. Taxon 57: 907-921.

Otálora, M. A. G., Aragón, G., Molina, M. C., Martínez, I. \& Lutzoni, F. (2010) Disentangling the CollemaLeptogium complex through a molecular phylogenetic study of the Collemataceae (Peltigerales, lichen-forming Ascomycota). Mycologia 102: 279-290.

Øvstedal, D. O. \& Gremmen, N. J. M. (2001) The lichens of Marion and Prince Edward Islands. South African fournal of Botany 67: 552-572.

Øvstedal, D. O. \& Gremmen, N. J. M. (2006) Lichens of sub-Antarctic Heard Island. South African fournal of Botany 72: 353-366.

Penn, O., Privman, E., Ashkenazy, H., Landan, G., Graur, D. \& Pupko, T. (2010) GUIDANCE: a web server for assessing alignment confidence scores. Nucleic Acids Research 38: W23-W28.

Posada, D. (2008) JModelTest: Phylogenetic Model Averaging. Molecular Biology and Evolution 25: 1253-1256.

Rambaut, A. (2009) FigTree v1.3.1. Edinburgh: Institute of Evolutionary Biology, University of Edinburgh. Available at http://tree.bio.ed.ac.uk/ software/figtree/

Rambaut, A. \& Drummond, A. J. (2007) Tracer version 1.5. Edinburgh: University of Edinburgh. Available at http://beast.bio.ed.ac.uk/Main

Reeb, V., Lutzoni, F. \& Roux, C. (2004) Contribution of RPB2 to multilocus phylogenetic studies of the euascomycetes (Pezizomycotina, Fungi) with special emphasis on the lichen-forming Acarosporaceae and evolution of polyspory. Molecular Phylogenetics and Evolution 32: 1036-1060.

Ronquist, F., Teslenko, M., van der Mark, P., Ayres, D., Darling, A., Höhna, S., Larget, B., Liu, L., Suchard, M. A. \& Huelsenbeck, J. P. (2011) MrBayes 3.2: efficient Bayesian phylogenetic inference and model choice across a large model space. Systematic Biology 61: 539-542.
Schmitt, I., Crespo, A., Divakar, P. K., Frankhauser, J. D., Herman-Sackett, E., Kalb, K., Nelsen, M. P., Rivas-Plata, E., Shimp, A. D., Widhelm, T., et al. (2009) New primers for promising single-copy genes in fungal phylogenetics and systematics. Persoonia 23: 35-40.

Spribille, T. \& Muggia, L. (2012) Expanded taxon sampling disentangles evolutionary relationships and reveals a new family in Peltigerales (Lecanoromycetidae, Ascomycota). Fungal diversity 59: 1-14.

Stamatakis, A. (2006) RAxML-VI-HPC: maximum likelihood-based phylogenetic analyses with thousands of taxa and mixed models. Bioinformatics 22: 2688-2690.

Stamatakis, A., Hoover, P. \& Rougemont, J. (2008) A rapid bootstrap algorithm for the RAxML web servers. Systematic Biology 57: 758-771.

Stiller, J. W. \& Hall, B. D. (1997) The origin of red algae: implications for plastid evolution. Proceedings of the National Academy of Sciences 94: 4520-4525.

Wedin, M., Wiklund, E., Crewe, A., Döring, H., Ekman, S., Nyberg, Å., Schmitt, I. \& Lumbsch, H. T. (2005) Phylogenetic relationships of Lecanoromycetes (Ascomycota) as revealed by analyses of $\mathrm{mtSSU}$ and nLSU rDNA sequence data. Mycological Research 109: 159-172.

Wedin, M., Wiklund, E., Jørgensen, P. M. \& Ekman, S. (2009) Slippery when wet: phylogeny and character evolution in the gelatinous cyanobacterial lichens (Peltigerales, Ascomycetes). Molecular Phylogenetics and Evolution 53: 862-871.

Wiens, J. J. (1998) Combining data sets with different phylogenetic histories. Systematic Biology 47: 568581.

Zahlbruckner, A. (1925) Catalogus Lichenum Universalis Vol. 3. Leipzig: Borntraeger.

Zoller, S., Scheidegger, C. \& Sperisen, C. (1999) PCR primers for the amplification of mitochondrial small subunit ribosomal DNA of lichen-forming ascomycetes. Lichenologist 31: 511-516. 